\title{
Coffee intake (Coffea arabica $L$.) reduces advanced glycation end product (AGEs) formation and platelet aggregation in diabetic rats
}

Alessandra dos Santos Danziger Silvério', Rosemary Gualberto Fonseca Alvarenga Pereira², Stella Maris da Silveira Duarte ${ }^{3}$, Sônia Aparecida Figueiredo ${ }^{3}$, Fernanda Borges de Araújo Paula ${ }^{3}$, Tomaz Henrique Araújo ${ }^{4}$, Cláudia de Souza Ferreira ${ }^{3}$, Bruno César Corrêa Salles ${ }^{3}$,

André Luiz Machado Viana ${ }^{3}$, Eric Batista Ferreira ${ }^{5}$, Maria Rita Rodrigues ${ }^{3 *}$ (1)

${ }^{1}$ Faculdade de Medicina, Universidade José do Rosário Vellano, Unifenas, Alfenas, MG, Brasil

2Departamento de Ciência dos Alimentos, Universidade Federal de Lavras, Lavras, MG, Brasil

${ }^{3}$ Departamento de Análises Clínicas e Toxicológicas, Faculdade de Ciências Farmacêuticas, Universidade Federal de Alfenas, Alfenas, MG, Brasil

${ }^{4}$ Instituto de Ciências Biomédicas, Universidade Federal de Alfenas, Alfenas, MG, Brasil

${ }^{5}$ Instituto de Ciências Exatas, Universidade Federal de Alfenas, Alfenas, MG, Brasil

*Corresponding author: rodrigues.mrita@gmail.com

\begin{abstract}
Objectives: The study aimed to determine the effect of coffee intake on AGEs formation and platelet aggregation in diabetic Wistar rats. Methods: Coffee powder samples were used to prepare a $10 \%$ beverage. Diabetes mellitus was induced in the animals by administering $2 \%$ alloxan. All animal experiments were approved by the ethics committee for animal experiments under $N^{\circ}$. 420/2012 and 536/2013. Diabetic and non-diabetic rats were divided into 6 groups treated and untreated with coffee $(7.2 \mathrm{~mL} / \mathrm{Kg}$ body weight) and aminoguanidine (AGE inhibiting agent) (100 mg/Kg body weight) for 50 days. After 50 days, the animals were fasted for $12 \mathrm{~h}$ and anesthetized (40 mg/Kg sodium pentobarbital) intraperitoneally. Blood samples were collected from the abdominal artery puncture. Hematological parameters (red cells, hemoglobin, hematocrit and leukocyte) and glycemic and HbA1c levels were measured. AGEs quantification (spectrofluorometric method) and the platelet aggregation test (aggregation of cuvettes in a fourchannel platelet aggregometer) were also conducted. The rats' renal function was evaluated by measuring serum urea and creatinine. Results: Data showed that coffee intake had no effect on the hematological parameters. Fasting glucose and HbA1c dosage were significantly higher in diabetic animals compared to non-diabetic animals (confirmed the effectiveness of inducing and maintaining diabetic status). Results showed that coffee reduced AGE formation and platelet aggregation in our animal model, not altering the animals' renal function. Conclusions: These results suggest beneficial effects on vasculopathy, a common complication in diabetic patients.
\end{abstract}

Keywords: Coffea arabica L. Diabetes Mellitus. End Products of Advanced Glycation. Aminoguanidine. Platelet Aggregation

\section{How to cite}

Silvério ASD, Pereira RGFA, Duarte SMS, Figueiredo SA, Paula FBA, Araújo TH, Ferreira CS, Salles BCC, Viana ALM, Ferreira EB, Rodrigues MR. Coffee intake (Coffea arabica L.) reduces advanced glycation end product (AGEs) formation and platelet aggregation in diabetic rats. Rev Ciênc Farm Básica Apl. 2021;42:e711. https://doi.org/10.4322/2179-443X.0711

Funding source: Nothing to declare.

Conflict of interests: The authors declare that there are no conflicts of interest regarding the publication of this article.

The study was carried out at Federal University of Alfenas (UNIFAL-MG), Alfenas, MG, Brazil.

Received on October 26, 2020. Accepted on December 09, 2020. 


\section{INTRODUCTION}

Diabetes mellitus (DM) is a chronic metabolic disease characterized by hyperglycemia that affects 415 million people worldwide, with an estimate for the coming decades of 642 million new cases $^{1,2}$. One of its causes may be the resistance of the insulin present in the body or the reduction in the amount of insulin produced (type $2 \mathrm{DM}$ ). Another manifestation of this disease occurs when the insulin-producing cells (pancreatic $\beta$ ) are destroyed, hindering hormone secretion (type $1 \mathrm{DM})^{2,3}$.

As the illness progresses, it may trigger disorders such as nephropathy, neuropathy, retinopathy (microvascular complications), coronary heart disease, peripheral vascular disease and heart failure (macrovascular complications) ${ }^{1,3,4}$.

Complications resulting from chronic hyperglycemia during DM are caused by oxidative stress triggered in different pathways, such as advanced glycation end products (AGEs) formation via polyol, protein kinase C (PKC) and hexosamine biosynthesis. These oxidative changes alter genetic expressions that damage pancreatic $\beta$ cells and induce insulin resistance ${ }^{5-8}$. Thus, AEGs formation act as one of the key factors that explain the ability of these compounds to alter the chemical and functional properties of various biological structures $^{9-11}$. Chronic hyperglycemia contributes significantly to endothelial injury by formation of free radicals, interactions with cellular receptors, or via cross-linking with proteins. The irreversible glycation of subendothelial collagen and other structural proteins changes vase structure and promotes vascular permeability and synthesis of proinflammatory cytokines, leading to diabetic complications such as macrovascular disorders ${ }^{10,12,13}$. Platelets, in turn, adhere to subendothelial components and are activated by cellular signaling, resulting in alteration, secretion and aggregation of the cellular form. Hyperglycemia has been reported to increase the propensity for platelets to aggregate and degranulate, leading to hypercoagulability ${ }^{14-16}$.

Currently, studies consider this chronic metabolic disorder as one of the main causes of increased morbidity and mortality in the world, constituting the main public health issue ${ }^{17-19}$.

Demand for diabetes treatment and prevention measures is imperative, and natural products with bioactive substances are currently a new research trend ${ }^{20}$. Phenolic compounds present in foods and beverages have been associated with a decreased risk of developing several chronic diseases ${ }^{1,21,22}$. Coffee, which contains chlorogenic acid as a main component, is the main source of phenolic compounds in the human diet ${ }^{23-25}$ and one of the most appreciated beverages worldwide ${ }^{20,22,26}$. Due to its potential protective effects on human health, coffee has gained prominence and has garnered the interest of researchers in the search for a treatment to chronic diseases ${ }^{18,19,21,27}$.

The chemical composition of the coffee bean is quite complex and depends on the variety, farming, processing type, roasting degree and grinding, and the brewing method ${ }^{20,28,29}$. Factors and dietary habits of coffee consumers, such as frequency of coffee intake, lifestyle, and genetic predisposition to developing certain diseases, can equally affect the possible effects of coffee on health ${ }^{30}$. Coffee consumption can affect key factors for blood sugar regulation, such as mechanisms of glucose capture in the intestine, hepatic gluconeogenesis and oxidative process in the liver ${ }^{20}$.

Containing a combination of bioactive components, especially phenols, coffee appears as one of the several therapeutic candidates studied in the search for compounds that can prevent complications caused by diabetes. This study aims to determine the effects of coffee on AGEs formation and platelet aggregation in diabetic rats.

\section{METHODS}

All in vivo experiments followed the ethical principles outlined for animal experimentation adopted by the guidelines of the International Council for Laboratory Animal Science (ICLAS) and were approved by the Ethical Committee for Animal Experimentation of UNIFAL-MG doc. $n^{\circ} 420 / 2012$ and 536/2013. 


\subsection{Coffee preparation and characterization}

The coffee (Coffea arabica L.) samples used in this study came from Fazenda Conquista (865 $\mathrm{m}$ altitude), belonging to Ipanema Agricola S.A., located in Alfenas, MG. The natural coffee beans were dried in the sun and resulted in $12 \%$ of the unit (gravimetric method Farmacopeia Brasileira ${ }^{31}$. They were roasted in a Probat roaster and then ground in a Raiar electric grinder (model RA21) in fine granulometry, vacuum-packed and stored at $-20^{\circ} \mathrm{C}$, until use.

For study, an aliquot powdered coffee was placed in a paper filter funnel (Whatman $\mathrm{N}^{\circ} 3$, General Electric Company), and water at $90{ }^{\circ} \mathrm{C}$ added over ${ }^{32}$, resulting in a beverage with a $10 \%$ concentration. These beverage samples were lyophilized for the chemical analyses ${ }^{28}$. For the bioassays, drinks were always prepared at the time of administration.

\subsection{Coffee administration, diabetes induction and treatment with an AGE inhibitor (aminoguanidine)}

All in vivo experiments followed the ethical principles outlined for animal experiments adopted by the International Council for Laboratory Animal Science (ICLAS) guidelines and were approved by the Ethics Committee for Animal Experiments of the Federal University of Alfenas, Alfenas, MG, Brazil (UNIFAL-MG) under n 420/2012 and 536/2013.

Male Wistar rats ( 22 weeks old, $320 \pm 20 \mathrm{~g}, \mathrm{n}=60$ ) were obtained from the animal house of the UNIFAL-MG and kept under controlled temperature of $23^{\circ} \mathrm{C}, 12 \mathrm{~h}$-light/dark conditions with food and water access ad libitum.

Filtered coffee beverages were administered daily to the animals by gavage corresponding to $7.2 \mathrm{~mL} / \mathrm{kg}$ body weight for a period of 50 days, which is equivalent to the daily human consumption of eight $50-\mathrm{mL}$ cups of coffee. The control group received the same dosage of water.

Diabetes was induced in animals kept fasting for 12 hours by intraperitoneal administration of alloxan ( $2 \%$ solution) at a dose of $150 \mathrm{mg} / \mathrm{kg}$ body weight ${ }^{33,34}$. We considered as diabetic the rats with glycemia above $250 \mathrm{mg} / \mathrm{dL}$ verified by the Trinder reaction, seven days after induction ${ }^{35}$. Blood glucose levels were measured weekly by collecting blood from the rats' tails to supervise the diabetic process.

The aminoguanidine (AMG) (Sigma Chemical Co, St. Louis-USA), AGE inhibiting agent, treatment was conducted by administering $100 \mathrm{mg} / \mathrm{kg}$ body weight by gavage for 50 days, starting seven days after alloxan administration and confirmed diabetic status ${ }^{36,37}$.

\subsection{Experiment design}

After a week of acclimatization, the rats were divided into 6 groups ( $n=10$ rats, group): non-diabetic rats treated with distilled water (ND), non-diabetic rats treated with aminoguanidine (ND + AMG), non-diabetic rats treated with full Arabica coffee (ND + CF), diabetic rats treated with distilled water (D), diabetic rats treated with aminoguanidine $(D+A M G)$, and diabetic rats treated with full Arabica coffee (D + CF).

On day 51, after treatment, the animals underwent fasting for 12 hours, and then anesthetized and euthanized via deep anesthesia ${ }^{37}$ after intraperitoneal administration of 40 $\mathrm{mg} / \mathrm{kg}$ of sodium pentobarbital., Blood samples for biological examinations were collected by abdominal artery puncture with a $19 \mathrm{G}$ needle and distributed in: siliconized test tubes without additives, siliconized tubes with ethylenediaminetetraacetic acid (EDTA), and tubes with sodium citrate. 


\subsection{Biological sample preparation and collection}

\subsubsection{Obtaining serum}

A blood aliquot was distributed in siliconized test tubes without additives containing gel separator. After blood clotting, the samples were centrifuged at $2000 \mathrm{~g}$ for 10 minutes. Serum was separated and used for evaluating blood glucose, renal profile and AGEs quantification ${ }^{38}$.

\subsubsection{Obtaining whole blood}

A blood aliquot was distributed in siliconized test tubes containing EDTA. Whole blood was used for determining glycated hemoglobin ( $\mathrm{HbA1}$ ) and hematological parameters.

\subsubsection{Obtaining platelet-rich plasma (PRP)}

Blood was collected by abdominal artery puncture and distributed in Falcon type centrifuge tubes containing anticoagulant citric acid $3 \% \mathrm{w} / \mathrm{v}$, trisodium citrate $4 \% \mathrm{w} / \mathrm{v}$, glucose $2 \% \mathrm{w} / \mathrm{v}$, sodium citrate $(A D C-C)$, at a 1:9 $(\mathrm{v} / \mathrm{v})$ ratio and homogenized. Then, the whole blood samples were centrifuged at $600 \mathrm{~g}$ for 12 minutes at room temperature within four hours after blood collection, to obtain platelet rich plasma (PRP) ${ }^{39}$.

\subsubsection{Obtaining washed platelet}

A wash buffer $(140 \mathrm{mM} \mathrm{NaCl}, 0.5 \mathrm{mM} \mathrm{KCl}, 12 \mathrm{mM}$ trisodium citrate, $10 \mathrm{mM}$ glucose and $12.5 \mathrm{mM}$ sucrose, $\mathrm{pH}$ 6) was added to the PRP at a 7:5 (buffer/plasma) ratio and then centrifuged for 13 minutes at $822 \mathrm{~g}$. The platelet pellet was resuspended in Krebs-Ringer solution devoid of calcium with $\mathrm{pH}$ precisely adjusted to track $7.2-7.4 \mathrm{CO}_{2}{ }^{39}$.

\subsection{Hematological parameters}

Hematological blood samples, collected in tubes containing EDTA, were processed in an Analyzer Counter 19 (Wiener Laboratories) to determine hematological parameters (red cells, hemoglobin, hematocrit, and leukocyte).

\subsection{Glycemic and HbA1c levels}

Blood glucose was determined by enzymatic method [39]. HbA1c was assessed by ion exchange chromatography (HPLC), using D-10 Hemoglobin A1c Program and Dual Program BIO-RAD ${ }^{\circledR} \mathrm{Kit}^{37}$.

\subsection{AGEs spectrofluorometric measure}

To quantify AGE-peptides we measured fluorescence according to Zilin et al. ${ }^{38}$. Serum samples $(70 \mu \mathrm{L})$ were treated with trichloroacetic acid (TCA) and chloroform, under vigorous agitation to precipitate proteins and extract lipids in the organic phase and were then centrifuged. Measurements were performed with a spectrofluorometer adjusted at wavelengths of $350 \mathrm{~nm}$ (excitation) and $440 \mathrm{~nm}$ (emission) with a gap width of $5 \mathrm{~nm}$. The results were expressed as arbitrary unit divided by the concentration of total proteins (method of Biuret - Layne) $)^{40}$ in the serum (AU/ mg protein) ${ }^{37,41}$.

\subsection{Hemostatic parameters}

Platelet count in the PRP followed the impedance method proposed by Wallace Counter automated apparatus (Wiener Lab. Counter 19).

To conduct the platelet aggregation test using the aggregation curve we initially performed a platelet count in the PRP, which were adjusted to 250.000 platelets $/ \mathrm{mm}^{3}$. After adjustment, the PRP was incubated with $1 \mathrm{mM}$ calcium chloride $\left(\mathrm{CaCl}_{2}\right)$, for 5 minutes at $37^{\circ} \mathrm{C}$, then added 
$1 \mu \mathrm{M}$ agent adenosine agonist $5^{\prime}$-diphosphate (ADP), and the variation of light transmission was monitored by standardized turbidimetric method for 5 minutes at $37^{\circ} \mathrm{C}$. The platelet aggregation measurements were carried out in bucket aggregations in 4-channel platelet aggregometer (Qualiterm) with ultimate reaction volume of $410 \mu \mathrm{L}^{39}$.

\subsection{Renal function biomarkers}

Urea and creatinine were measured by a commercial kit according to the manufacturers' instructions and using an automatic analyzer (HumanStar, InVitro Diagnóstica $\left.{ }^{\circledR}\right)^{37}$.

\subsection{Statistical analysis}

Three experiments were conducted in Completely Randomized Design (CRD) and analyzed under double factorial scheme ( 2 levels of diabetes and 3 levels of inhibitors). Tukey test was performed for qualitative factors, when necessary ( $5 \%$ of significance level).

Eventual missing data were estimated by analysis of variance in a linear model, resulting in a balanced scores table.

All analyses were performed in R (R CORE TEAM ${ }^{42}$ using ExpDes package ${ }^{43}$.

\section{RESULTS}

We evaluated the animals' hematological parameters (red cells, hemoglobin, hematocrit, and leukocyte measurements) to verify whether the diabetes induction or treatments with coffee and AMG modified the erythrogram and the number of leukocytes in these animals.

For the mean erythrocyte count, we observed no differences between the diabetic and nondiabetic groups (Table 1). AMG treatment and coffee intake effected no change on the rats' erythrocyte profile and leukocyte counts. The obtained data suggest that coffee consumption does not alter hemoglobin levels or the number of circulating red blood cells and leukocytes when animals have a balanced diet.

Table 1. Determination of the rats' hematological parameters in the different treatment groups.

\begin{tabular}{|c|c|c|c|c|}
\hline Parameters & $\operatorname{Hem}\left(\times 10^{12} L\right)$ & $\mathrm{Hb}(\mathrm{g} / \mathrm{dL})$ & Ht (\%) & Leuk $\left(\mathrm{mm}^{3}\right)$ \\
\hline Non-diabetic & $8.7( \pm 0.4)$ & $16.7( \pm 0.7)$ & $46.0( \pm 1.5)$ & $5785.0( \pm 348.4)$ \\
\hline Diabetic & $8.8( \pm 0.4)$ & $17.2( \pm 1.1)$ & $48.7( \pm 2.9)$ & $5522.0( \pm 243.8)$ \\
\hline$N D+A M G$ & $8.6( \pm 0.6)$ & $17.0( \pm 0.4)$ & $46.6( \pm 2.0)$ & $5825.0( \pm 436.7)$ \\
\hline$D+A M G$ & $8.6( \pm 0.5)$ & $17.1( \pm 1.1)$ & $47.9( \pm 2.8)$ & $5514.0( \pm 402.9)$ \\
\hline$N D+C F$ & $8.8( \pm 0.5)$ & $17.9( \pm 0.3)$ & $47.7( \pm 1.9)$ & $5542.0( \pm 395.2)$ \\
\hline$D+C F$ & $8.7( \pm 0.5)$ & $17.0( \pm 1.0)$ & $47.8( \pm 2.9)$ & $5275.0( \pm 377.0)$ \\
\hline
\end{tabular}

The results represent the mean \pm standard deviation (SD) for five measurements per treatment.

Non-diabetic: non-diabetic animals, Diabetic: diabetic animals, ND + AMG: non-diabetics animals treated with aminoguanidine, ND + CF: non-diabetics animals treated with coffee, D + AMG: diabetic animals treated with aminoguanidine, D + CF: diabetic animals treated with coffee, Hem: red blood cells, Hb: hemoglobin, Ht: hematocrit, Leuk: leucocytes. The data statistical analysis showed no statistically significant difference between the groups and treatments performed.

The fasting glucose (kept above $250 \mathrm{mg} / \mathrm{dL}$ throughout the experiment) and HbA1c levels were significantly higher in diabetic animals (D) compared with non-diabetic animals (ND) (Figure 1), showing the effectiveness of alloxan in inducing and maintaining diabetic conditions throughout the experiment. Here, coffee intake had no effect on fasting blood glucose and $\mathrm{HbA} 1 \mathrm{c}$ levels for either group (Figure 1). As expected, the HbA1c levels decreased in diabetic animals treated with AMG, a known glycation inhibitor (Figure 1). 


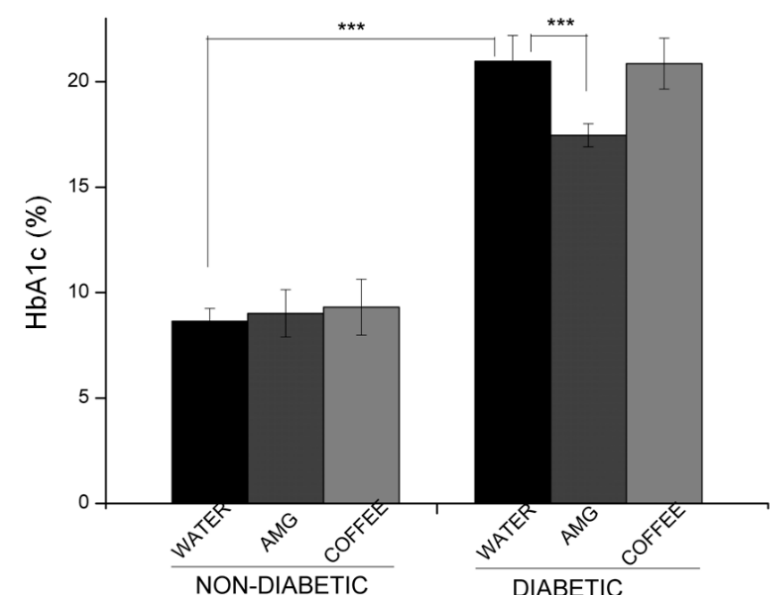

Figure 1. Measurement of glycated hemoglobin $(\mathrm{HbA} 1 \mathrm{c})$ percentage in rats. Values are presented as mean \pm SD of the three experiments performed in triplicate to measure the HbA1c percentage in the non-diabetic and diabetic groups. Non-diabetic and diabetic rats were treated with water, aminoguanidine (AMG) or coffee. SD: standard deviation. ${ }^{* \star} p<0.001$ indicates statistical difference.

Circulating levels of fluorescent AGEs were significantly higher in diabetic animals compared with non-diabetic animals (Figure 2). AGEs serum concentration decreased in both groups treated with AMG (Figure 2). As expected, our results show an efficacy of AMG treatment in preventing AGEs formation in diabetic animals. Coffee was as efficient as AMG in reducing AGEs formation in diabetic animals (Figure 2 ).

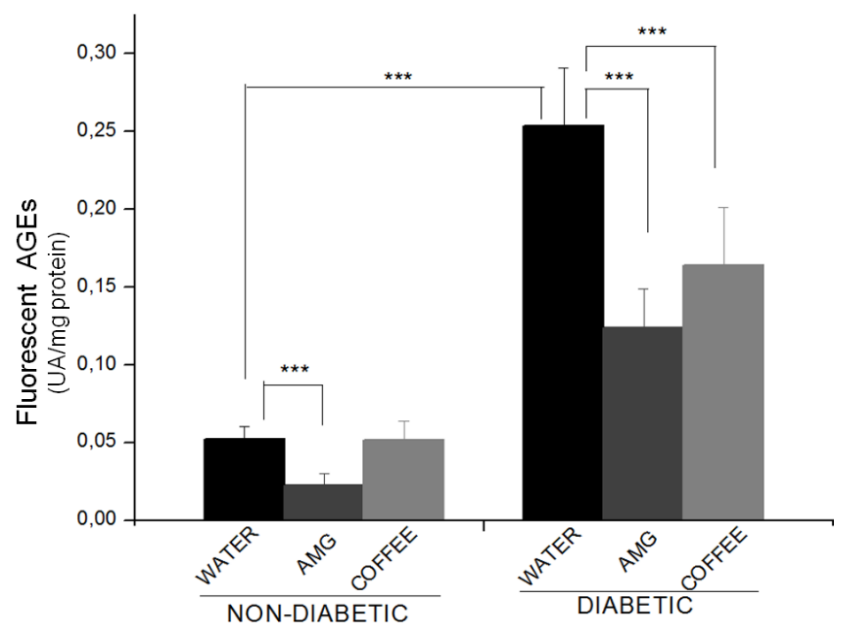

Figure 2. Determination of fluorescent advanced glycation end products (AGEs) in rat's serum. Values are presented as mean \pm SD of the three experiments performed in triplicate to measure serum fluorescent AGEs in the non-diabetic and diabetic groups. Non-diabetic and diabetic rats were treated with water, aminoguanidine (AMG) or coffee. SD: standard deviation. ${ }^{* \star} p<0.001$ indicates statistical difference.

To assess the effects of coffee on primary hemostasis in diabetic rats, we measured the platelet aggregation against the ADP agonist ${ }^{26}$. Platelet aggregation significantly increased in the diabetic animals (Figure 3), suggesting an excess of glucose-induced osmotic effect and reactive oxygen species (ROS) in the serum. 


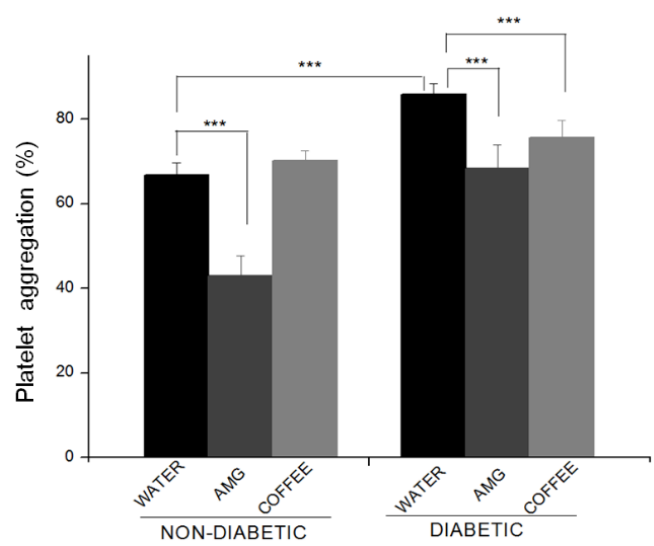

Figure 3. Evaluation of platelet aggregation percentage in rats. Values are presented as mean \pm SD of the three experiments performed in triplicate to measure platelet aggregation in the non-diabetic and diabetic groups. Non-diabetic and diabetic rats were treated with water, aminoguanidine (AMG) or coffee. SD: standard deviation. ${ }^{* *} p<0.001$ indicates statistical difference.

We observed that AMG significantly reduced platelet aggregation in non-diabetic and diabetic animals (Figure 3). Our results show that coffee reduced platelet aggregation in diabetic animals to levels comparable to those of the non-diabetic group (Figure 3).

Finally, we evaluated the renal parameters in both animal groups by measuring urea and creatinine levels. Diabetic rats had significantly higher levels of urea in the serum (Figure 4A). Hyperglycemia did not alter the serum creatinine levels, that is, we found no kidney damage due to hyperglycemia in the evaluated period (Figure 4B). The AMG treatment or coffee intake had no effect on these animals' renal profile.

A

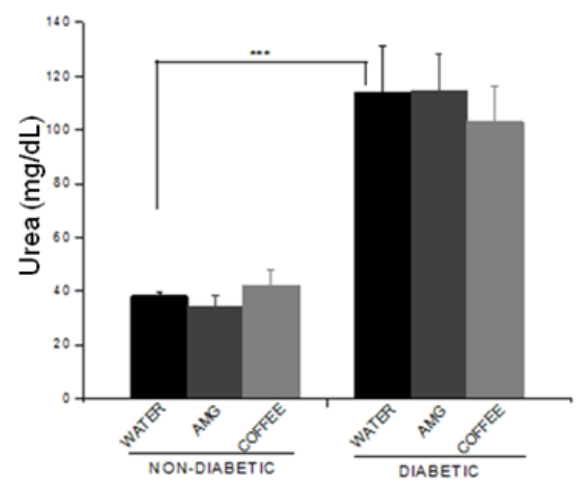

B

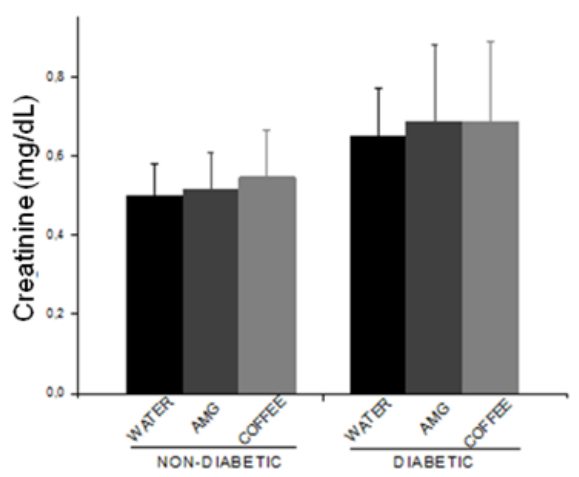

Figure 4. Determination of the rats' renal profile with serum urea $(\mathrm{mg} / \mathrm{mL})(A)$ and creatinine $(\mathrm{mg} / \mathrm{mL})$ (B) measurements. Values are presented as mean \pm SD of the three experiments performed in triplicate to measure serum urea and creatinine in the non-diabetic and diabetic groups. Non-diabetic and diabetic rats were treated with water, aminoguanidine (AMG) or coffee. SD: standard deviation. ${ }_{* * *} p<0.001$ indicates statistical difference.

\section{DISCUSSION}

The search for therapeutic plants for treating diabetes mellitus has been stimulated by the World Health Organization (WHO) due to low side effects from their prolonged and traditional use, in addition to being a low cost and significantly effective therapeutic alternative ${ }^{44}$. 
Coffee is a fruit rich in bioactive compounds, such as caffeine, trigonelline, chlorogenic acids, phenolic compounds, diterpenes and melanoidins. Its long-term consumption has shown beneficial effects in chronic diseases such as diabetes ${ }^{45}$. The decreased risk of developing chronic diseases has been related to the presence of phenolic compounds $\mathrm{s}^{1,21,22}$.

Untreated chronic hyperglycemia leads to macro and microvascular diabetic complications. The progression of these complications triggers multiple renal, cardiac and hepatic disorders and, consequently, derangements in the biochemical, hematological and histological parameters that contribute to increase free radicals, associated with the pathophysiology of diabetes ${ }^{44}$.

In the present study, the diabetic status did not alter the number of leukocytes (Table 1); but this change can occur and is typical of the damage caused by induced diabetes, as reported by ${ }^{46}$. The other parameters ( $\mathrm{Hem}$ and $\mathrm{Hb}$ ) also showed no statistical change. Hyperglycemia can modify red blood cell count and cause oxidative stress, hemoglobin glycation and other hematological disorders ${ }^{46}$. Studies have shown the ability of phenolic compounds to form complexes with Fe (II), present in large quantities in the hemoglobin molecule, which could interfere with its absorption in the gastrointestinal tract and consequently lead to iron deficiency ${ }^{47-49}$. The doses of coffee consumption used in this study, however, were unable to change the hematological parameters in rats with a balanced diet.

Regarding the glycemic profile, diabetes induction and maintenance was confirmed in animals by the increase in fasting glucose and glycated hemoglobin levels (Figure 1). Among the bioactive substances present in coffee, caffeine has controversial effects on blood glucose levels. While short-term metabolic studies performed in humans have shown that caffeine at acute doses reduces insulin sensitivity due to its rapid metabolism ${ }^{27,50,51}$, others have observed increased sensitivity in insulin receptors upon caffeine treatment ${ }^{52}$. Long-term coffee consumption can induce glucose tolerance and insulin sensitivity, helping to prevent diabetes symptoms and improving insulin sensitivity ${ }^{53}$.

Several mechanisms have been proposed to explain the beneficial effect of coffee on glucose, insulin homeostasis and diabetes progression. This protective effect can be attributed to other coffee components such as chlorogenic acid and their derivatives - lignans, trigonelline, N-methylpyridinium, minerals and vitamins, proteins and lipids (diterpenes) (19,20. $^{\text {. }}$ These compounds can act on harmful free radicals, participate in cell signaling pathways performing, among other functions, anti-glycation activity ${ }^{54}$. Chlorogenic acids and their derivatives represent the most prevalent phenolic compounds in coffee 20,55 .

The HbA1c level is an important biomolecular marker. It is a chromatographic fraction of hemoglobin that carries an Amadori product in its $\beta$ chain and that reflects the occurrence of hyperglycemia in the three months prior to its measurement and, indirectly, advanced glycation ${ }^{56}$. After 50 days of treatment, measuring this marker also confirmed the diabetic state induced in the animals.

AMG, an agent commonly used to prevent AGEs formation in animal models, is effective in reducing AGEs and lowering the severity of diabetes-associated structural and functional alterations ${ }^{37,57}$. The use of a treatment that blocks AGEs or reduces oxidative and nitrosative stress can be effective in controlling diabetic complications.

The contribution of AGEs in the development and progression of diabetic complications is well established $1,10,37,58$. AGEs may act by modifying intracellular functional proteins involved in gene regulation in the nearby extracellular matrix molecules, by interfering in the signaling between the matrix and the cell causing dysfunction in proteins such as albumin. AGE accumulation results in endothelial dysfunction, fibrosis, chronic inflammation and, consequently, in generalized cellular dysfunction ${ }^{1,10,59}$.

As AGEs are one of the main factors that could potentially explain how chronic hyperglycemia leads to the cell and tissue damage observed in diabetes, we measured the serum concentration of the well characterized and widely studied fluorescent AGEs pentosidine and argipiridine in the animals ${ }^{60}$. Circulating levels of fluorescent AGE-peptides were significantly higher in diabetic animals compared with the non-diabetic animals (Figure 2). These results were similar to those found by Ferreira et al. ${ }^{37}$. Although it has already been 
shown that AGE production increases significantly under hyperglycemia or oxidative stress, several of its mechanical details remain unclear ${ }^{1,10,61,62}$. As mentioned above, AGEs serum concentration significantly decreased in aminoguanidine-treated diabetic and non-diabetic rats (Figure 2). Our results show the effectiveness of aminoguanidine treatment in preventing AGE formation in diabetic animals. These data are consistent with the results obtained previously by Ferreira et al. ${ }^{37}$. Similarly, coffee efficiently reduced AGE formation in diabetic animals (Figure 2).

There has been significant interest in identifying dietary components that combat or attenuate diabetic complications by reducing AGEs accumulation or inhibiting its effects on the body ${ }^{63,64}$. Although no food component has been specified as being anti-AGE in vivo, certain coffee components, such as phenolic compounds, have been intensively studied and shown to have the ability to inhibit AGE formation ${ }^{63}$.

Being highly damaging to the integrity and function of blood vessels, AGEs result in the main cause of diabetes complications related to vasculopathy ${ }^{64,65}$. The interaction of AGEs with components of the vessel wall increases vascular permeability, expression of procoagulant activity and ROS generation, resulting in increased leukocyte adhesion molecules in the endothelial layer ${ }^{65}$. Additionally, platelet-monocyte aggregates and platelet hyperactivity are important factors commonly associated with chronic diabetes complications ${ }^{26,66}$.

Diabetic patients generally present symptoms of hypercoagulability and hypofibrinolysis, but the degree of hemostatic abnormality in these patients is still poorly understood. To evaluate the effects of coffee on primary hemostasis in diabetic rats, we measured the platelet aggregation against the ADP agonist ${ }^{26}$. Platelet aggregation significantly increased in the diabetic animals (Figure 3), suggesting an excess of glucose-induced osmotic effect and ROS in the serum, leading to platelet aggregation and degranulation and, consequently, decreased endothelial functions ${ }^{26,67}$. Increased platelet activity and thrombus formation has been suggested to play a role in diabetes, atherosclerosis, cardiac disease, and hypertension ${ }^{26,68}$. Several studies have shown increased platelet reactivity in diabetic patients by increased levels of specific markers, such as beta-thromboglobulin and platelet factor 4 in platelet granules in plasma ${ }^{69}$, and increased expression of platelet membrane glycoproteins GPIb and GPIIb/IIla. Reduced membrane fluidity has also been correlated with glycation of platelet membrane proteins ${ }^{70,71}$.

We observed that aminoguanidine significantly reduced platelet aggregation in nondiabetic and diabetic animals (Figure 3 ). This result may be explained by its antioxidant activity $^{72}$, which blocks protein glycation and can reduce reactivity changes in platelets, thus helping ameliorate the endothelial dysfunction that is intrinsic to diabetes.

AGE-induced pathogenesis of diabetic micro- and macroangiopathy is well established in the literature ${ }^{10,73,74}$. As kidneys are the major site for AGE clearance, they constitute the main target of deleterious AGE-mediated changes ${ }^{75}$. The severity of vascular damage in renal tissue may result from a decline in soluble RAGE (SRAGE) and the AGEs/SRAGE ratio; associated with urinary albumin/serum creatinine levels, it can measure reno-vascular complications in diabetic patients ${ }^{10}$. Thus, we evaluated the renal function in both animal groups by measuring urea and creatinine levels. Diabetic rats showed significantly higher levels of urea in the serum, and aminoguanidine treatment or coffee intake effected no change in these animals' renal profile (Figure 4A). Urea, the main product of protein catabolism in the liver, is synthesized from $\mathrm{CO}_{2}$ and ammonia and circulates in the blood before being filtered in the kidneys, where most of it is excreted in urine. Urea levels are sensitive to changes, appear faster in primary renal functions, and is an important marker in conditions that affect primary renal function alterations, like diabetes ${ }^{37,76}$. DM2 promotes progressive cachexia, which causes skeletal muscle atrophy ${ }^{77}$ - result of the imbalance on protein synthesis in favor of its proteolysis. Excessive proteolysis results in an increase in plasma urea, as observed in the study. The atrophy stems from reduced insulin-like growth factor 1 (IGF-1) and hyperglycemic conditions ${ }^{78}$. But as urea concentration is influenced by hydration levels and dietary habits, it is less specific than creatinine for assessing renal function. 
In this study, coffee intake or aminoguanidine treatment had no effect on serum creatinine levels in the diabetic animals (Figure 4B). Creatinine, which is a breakdown product of creatine phosphate in muscle, is usually produced at a constant rate and its levels are directly proportional to muscle mass. Interestingly, creatinine levels also reflect the glomerular filtration rate, for its concentration in the blood increases as the renal filtration rate declines ${ }^{79}$. According to Fagbohun et al. ${ }^{44}$, plasma creatinine acts as a better indicator of stage 1 kidney toxicity than urea.

Our results showed that aminoguanidine did not alter renal biomarkers. Although not evaluated in this work, recent studies have shown that this AGE-inhibitor can alter liver markers such as alanine aminotransferase (ALT), aspartate aminotransferase (AST) and alkaline phosphatase (ALP) $)^{80}$.

It is important to highlight that the coffee variety, roasting process, and method of brewing, among other variables, changes the amount of bioactive components, such as chlorogenic acid, caffeine, and melanoidins, in the beverage. Such components are the main responsible for the antioxidative effects of coffee and can alter the effects described in other studies.

Thus, it is possible to conclude that the study results showed that coffee intake reduced AGEs formation and platelet aggregation in our experimental model. The protective role of coffee may result from the action of its bioactive components, such as chlorogenic acid. Aminoguanidine was effective in inhibiting AGE formation and platelet aggregation. We also observed that coffee had no effect on the animals' renal function. These results are especially interesting because diabetes is an important risk factor for thrombosis, characterized by hypercoagulability and hypofibrinolysis, and coffee is a widely consumed beverage in the contemporary world.

\section{REFERENCES}

1. Jud P, Sourij $\mathrm{H}$. Theraoeutic options to reduce advanced glycation end products in patients with diabetes ellitus: A review. Diabetes Res Clin Pract. 2019;148:54-63. http://dx.doi.org/10.1016/j.diabres.2018.11.016. PMid:30500546.

2. Pang M, Li Y, Gu W, Sun Z, Wang Z, Li L. Recent Advances in Epigenetics of Macrovascular Complications in Diabetes mellitus. Heart Lung Circ. 2020;30(2):186-196.

3. Mirza S, Khan AA, Al-Kheraif AA, Khan SZ, Shafqat SS. Efficacy of adjunctive photodynamic therapy on the clinical periodontal, $\mathrm{HbA} 1 \mathrm{c}$ and advanced glycation end product level among mild to moderate chronic periodontal disease patients with type 2 diabetes mellitus: A randomized controlled clinical trial., Photodiagn Photodyn Ther. 2019;28:177-82. http://dx.doi.org/10.1016/j.pdpdt.2019.08.003. PMid:31394300.

4. Triches C, Schaan B, Gross JL, Azevedo MJ. Complicações macrovasculares do diabetes melito: peculiaridades clínicas, de diagnóstico e manejo. Arq Bras Endocrinol Metabol. 2009;53(6):698-708. http://dx.doi.org/10.1590/S0004-27302009000600002. PMid:19893911.

5. Reis JS, Veloso CA, Mattos RT, Purish S, Nogueira-Machado JA. Estresse oxidativo: revisão de sinalização metabólica no diabetes tipo 1. Arq Bras Endocrinol Metabol. 2008;52(7):1096-105. http://dx.doi.org/10.1590/S0004-27302008000700005. PMid:19082297.

6. Sheweita SA, ElHady SA, Hammoda HM. Trigonella stellate reduced the deleterious effects of diabetes mellitus through alleviation of oxidative stress, antioxidant- and drug-metabolizing enzymes activities. J Ethnopharmacol. 2020;256:112821. http://dx.doi.org/10.1016/j.jep.2020.112821. PMid:32251758.

7. Wu CH, Huang HW, Lin JA, Huang SM, Yen GC. The proglycation effect caffeic acid leads to the elevation of oxidative stress and inflammation in monocytes, macrophages and vascular endothelial cells. J Nutr Biochem. 2011;22(6):585-95. http://dx.doi.org/10.1016/j.jnutbio.2010.05.002. PMid:20951562.

8. Zeng C, Li Y, Ma J, Niu L, Tay FR. Clinical/Translational aspects of advanced glycation end-products. Trends Endocrinol Metab. 2019;30(12):959-73. http://dx.doi.org/10.1016/j.tem.2019.08.005. PMid:31597608.

9. Brownlee M. Biochemistry and molecular cell biology of diabetic complications. Nature. 2001;414(6865):813-20. http://dx.doi.org/10.1038/414813a. PMid:11742414. 
10. Farhan SS, Hussain SA. Advanced glycation end products (AGEs) and their soluble receptors (SRAGE) as early predictors of reno-vascular complications in patients with uncontrolled type 2 diabetes mellitus. Diabetes Metab Syndr. 2019;13(4):2457-61. http://dx.doi.org/10.1016/j.dsx.2019.06.019. PMid:31405660.

11. Peppa M, Uribarri J, Vlassara H. Glucose, advanced glycation end products, and diabetes complications: what is new and what works. Clin Diabetes. 2003;21(4):186-7. http://dx.doi.org/10.2337/diaclin.21.4.186.

12. Borissoff Jl, Spronk HMH, ten Cate $\mathrm{H}$. The hemostatic system as a modulator of atherosclerosis. $\mathrm{N}$ Engl J Med. 2011;364(18):1746-60. http://dx.doi.org/10.1056/NEJMra1011670. PMid:21542745.

13. Reasner CA. Reducing cardiovascular complications of type 2 diabetes by targeting multiple risk factors. J Cardiovasc Pharmacol. 2008;52(2):136-44. http://dx.doi.org/10.1097/FJC.0b013e31817ffe5a. PMid:18670366.

14. Barg A, Ossig R, Goerge T, Schneider MF, Schillers H, Oberleithner H, Schneider SW. Soluble plasmadeived Von Willebrand factor assembles to a haemostatically active filamentous network. J Thromb Haemost. 2007;97(4):514-26. http://dx.doi.org/10.1160/TH06-05-0274. PMid:17393012.

15. Gray E, Mulloy B, Barrowcliffe TW. Heparin and low-molecular-weight heparin. J Thromb Haemost. 2008;99(5):807-18. PMid:18449410.

16. Michelson AD. Antiplatelet therapies for the treatment of cardiovascular disease. Nat Rev Drug Discov. 2010;9(2):154-69. http://dx.doi.org/10.1038/nrd2957. PMid:20118963.

17. American Diabetes Association. Position statement: standards of medical care in diabetes. Diabetes Care. 2013;36:11-66.

18. Fangel MV, Nielsen PB, Kristensen JK, Larsen TB, Overvad TF, Lip GYH, Jensen MB. Albuminuria and risk of cardiovascular events and mortality in a general population of patients with Type 2 diabetes without cardiovascular disease: a danish cohort study. Am J Med. 2020;133(6):e269-79. http://dx.doi.org/10.1016/j.amjmed.2019.10.042. PMid:32205071.

19. Mirmiran P, Carlström M, Bahadoran Z, Azizi F. Long-term effects of coffee and caffeine intake on the risk of pre-diabetes and type 2 diabetes: findings from a population with low coffee consumption. Nutr Metab Cardiovasc Dis. 2018;28(12):1261-6. http://dx.doi.org/10.1016/j.numecd.2018.09.001. PMid:30352712.

20. Costabile A, Sarnsamak K, Hauge-Evans AC. Coffee, type 2 diabetes and pancreatic islet function - A mini-review. J Funct Foods. 2018;45:409-16. http://dx.doi.org/10.1016/j.jff.2018.04.011.

21. Muñoz E, Hernández SS, Tolosa AR, Burillo SP, Olalla-Herrera M. Evaluation of differences in the antioxidant capacity and phenolic compounds of green and roasted coffee and their relationship with sensory properties. Lebensm Wiss Technol. 2020;128:109457. http://dx.doi.org/10.1016/j.Iwt.2020.109457.

22. Vithana MDK, Singh Z, Johnson SK. Harvest maturity stage affects the concentrations of healthpromoting compounds: Lupeol, mangiferin and phenolic acids in the pulp and peel of ripe 'Kensington Pride' mango fruit. Sci Hortic (Amsterdam). 2019;243:125-30. http://dx.doi.org/10.1016/j.scienta.2018.08.019.

23. Gómez-Ruiz JA, Leake DS, Ames JM. In vitro antioxidant activity of coffee compounds and their metabolites. J Agric Food Chem. 2007;5(17):6962-9. http://dx.doi.org/10.1021/jf0710985. PMid:17655324.

24. Lafay S, Morand C, Manach C, Besson C, Scalbert A. Absorption and metabolism of caffeic acid and chlorogenic acid in the small intestine of rats. Br J Nutr. 2006;96(1):39-46. http://dx.doi.org/10.1079/BJN20061714. PMid:16869989.

25. Natella F, Scaccini C. Role of coffee in modulation of diabetes risk. Nutr Rev. 2012;70(4):207-17. http://dx.doi.org/10.1111/j.1753-4887.2012.00470.x. PMid:22458694.

26. Olas B, Bryś M. Effects of coffee, energy drinks and their components on hemostasis: the hypothetical mechanisms of their action. Food Chem Toxicol. 2019;127:31-41. http://dx.doi.org/10.1016/j.fct.2019.02.039. PMid:30844438.

27. Reis CEG, Dórea JG, da Costa THM. Effects of coffee consumption on glucose metabolism: A systematic review of clinical trials. J Tradit Complement Med. 2019;9(3):184-91. http://dx.doi.org/10.1016/j.jtcme.2018.01.001. PMid:31193893. 
28. Lima AR, Pereira RGFA, Abrahão SA, Duarte SMS, Paula FBA. Compostos bioativos do café: atividade antioxidante in vitro do café verde e torrado antes e após a descafeinação. Quim Nova. 2010;33(1):20-4. http://dx.doi.org/10.1590/S0100-40422010000100004.

29. Tripetch $P$, Borompichaichartkul C. Effect of packaging materials and storage time on changes of colour, phenolic content, chlorogenic acid and antioxidant activity in Arabica green coffee beans (Coffea Arabica L. cv. Catimor). J Stored Prod Res. 2019;84:101510. http://dx.doi.org/10.1016/j.jspr.2019.101510.

30. Higdon JV, Frei B. Coffee and health: a review of recent human research. Crit Rev Food Sci Nutr. 2006;46(2):101-23. http://dx.doi.org/10.1080/10408390500400009. PMid:16507475.

31. Farmacopeia Brasileira. Métodos de Farmacognosia. Métodos de análises de drogas vegetais. Determinação de água em drogas vegetais. 5. ed. Brasília: ANVISA; 2017. p. 54.

32. Duarte SMS, Abreu CMP, Menezes HC, Santos MR, Gouvêa CMCP. Effect of processing and roasting on the antioxidant activity of coffee brews. Ciência Tecnol Alime. 2005;25(2):387-93. http://dx.doi.org/10.1590/S0101-20612005000200035.

33. Ferreira C, Araújo TH, Ângelo ML, Pennacchi PC, Okada SS, Paula FBA, Migliorini S, Rodrigues MR. Neutrophil dysfunction induced by hyperglycemia: modulation of myeloperoxidase activity. Cell Biochem Funct. 2012;30(7):604-10. http://dx.doi.org/10.1002/cbf.2840. PMid:22610543.

34. Szkudelski T. The mechanism of alloxan and streptozotocin action in B cells of the rat pancreas. Physiol Res. 2001;50(6):537-46. PMid:11829314.

35. Stoppa GR, Cesquini M, Roman EA, Ogo SH, Torsoni MA. Aminoguanidine prevented impairment of blood antioxidant system in insulin-dependent diabetic rats. Life Sci. 2006;78(12):1352-61. http://dx.doi.org/10.1016/j.Ifs.2005.07.031. PMid:16229859.

36. Edelstein D, Brownlee M. Aminoguanidine ameliorates albuminuria in diabetic hypertensive rats. Diabetologia. 1992;35(1):96-7. http://dx.doi.org/10.1007/BF00400859. PMid:1541387.

37. Ferreira CS, Pennacchi PC, Araújo TH, Taniwaki NN, Paula FBA, Duarte SMS, Rodrigues MR. Aminoguanidine treatment increased NOX2 response in diabetic rats: improved phagocytosis and killing of Candida albicans by neutrophils. Eur J Pharmacol. 2016;772:83-91. http://dx.doi.org/10.1016/j.ejphar.2015.12.044. PMid:26724393.

38. Zilin S, Naifeng L, Bicheng L, Jiping W. The determination of AGE-peptides by flow injection assay, a practical marker of diabetic nephropathy. Clin Chim Acta. 2001;313(1-2):69-75. http://dx.doi.org/10.1016/S0009-8981(01)00651-9. PMid:11694241.

39. Silvério ASD, Pereira RGFA, Lima AR, Paula FBA, Rodrigues MR, Baldissera L Jr, Duarte SM. The effects of the decaffeination of coffee samples on platelet aggregation in hyperlipidemic rats. Plant Foods Hum Nutr. 2013;68(3):268-73. http://dx.doi.org/10.1007/s11130-013-0365-x. PMid:23780748.

40. Layne E. Spectrophotometric and Turbidimetric Methods for Measuring Proteins. Methods Enzymol. 1957;10:447-55. http://dx.doi.org/10.1016/S0076-6879(57)03413-8.

41. Alhamdani MS, Al-Azzawie HF, Abbas FK. Decreased formation of advanced glycation end-products in peritoneal fluid by carnosine and related peptides. J Int Society Perit Dial., 2007;27(1):86-9. http://dx.doi.org/10.1177/089686080702700118. PMid:17179517.

42. R Core Team (2020). R: A language and environment for statistical computing. R Foundation for Statistical Computing, Vienna, Austria. https://www.R-project.org/

43. Ferreira EB, Cavalcanti PP, Nogueira DA. ExpDes: Experimental Designs package. R package version 1.1.2; 2013.

44. Fagbohun OF, Awoniran PO, Babalola OO, Agboola FK, Msagati TAM. Changes in the biochemical, hematological and histopathological parameters in STZ-Induced diabetic rats and the ameliorative effect of Kigelia africana fruit extract. Heliyon. 2020;6(5):e03989. http://dx.doi.org/10.1016/j.heliyon.2020.e03989. PMid:32462092.

45. Wang X, Meng Q, Peng X, Hu G, Qiu M. Identification of new diterpene esters from greens Arabica coffee beans, and their platelet aggregation accelerating activities. Food Chem. 2018;263:251-7. http://dx.doi.org/10.1016/j.foodchem.2018.04.081. PMid:29784314.

46. Hajam YA, Rai S, Ghosh H, Basheer M. Combined administration of exogenous melatonin and insulin ameliorates streptozotocin induced toxic alteration on hematological parameters in diabetic male Wistar rats. Toxicol Rep. 2020;7:353-9. http://dx.doi.org/10.1016/j.toxrep.2020.01.020. PMid:32095432. 
47. Szajdek A, Borowska EJ. Bioactive Compounds and Health-Promoting Properties of Berry Fruits: A Review. Plant Foods Hum Nutr. 2008;63(4):147-56. http://dx.doi.org/10.1007/s11130-008-0097-5. PMid:18931913.

48. Elhabiri M, Carrër C, Marmolle F, Traboulsi H. Complexation of iron (III) by catecholate-type polyphenols. Inorg Chim Acta. 2007;360(1):353-9. http://dx.doi.org/10.1016/j.ica.2006.07.110.

49. Mennen LI, Walker R, Bennetau-Pelissero C, Scalbert A. Risks and safety of polyphenol consumption. Am J Clin Nutr. 2005;81(1, Suppl):326S-9S. http://dx.doi.org/10.1093/ajcn/81.1.326S. PMid:15640498.

50. Keijzers GB, de Galan BE, Tack CJ, Smits P. Caffeine can decrease insulin sensitivity in humans. Diabetes Care. 2002;25(2):364-9. http://dx.doi.org/10.2337/diacare.25.2.364. PMid:11815511.

51. Thong FS, Derave W, Kiens B, Graham TE, Urso B, Wojtaszewski JF, Hansen BF, Richter EA. Caffeineinduced impairment of insulin action but not insulin signaling in human skeletal muscle is reduced by exercise. Diabetes. 2002;51(3):583-90. http://dx.doi.org/10.2337/diabetes.51.3.583. PMid:11872654.

52. van Dam RM, Willett WC, Manson JE, Hu FB. Coffee, caffeine, and risk of type 2 diabetes: a prospective cohort study in younger and middle-aged U.S. women. Diabetes Care. 2006;29(2):398403. http://dx.doi.org/10.2337/diacare.29.02.06.dc05-1512. PMid:16443894.

53. Akash MSH, Rehman K, Chen S. Effects of coffee on type 2 diabetes mellitus. Nutrition. 2014;30(78):755-63. http://dx.doi.org/10.1016/j.nut.2013.11.020. PMid:24984989.

54. Khan M, Liu H, Wang J, Sun B. Inhibitory effect of phenolic compounds and plant extracts on the formation of advance glycation end products: A comprehensive review. Food Res Int. 2020;130:108933. http://dx.doi.org/10.1016/j.foodres.2019.108933. PMid:32156381.

55. Clifford MN. Chlorogenic Acids. Coffee. 1985;1:153-202. http://dx.doi.org/10.1007/978-94-009-4948-5_5.

56. Mustafa IO, Tanko Y, Yusuf R, Musa SA. The use of glycated haemoglobin (HbA1c) in determining glycemic control (and relevance of BMI) in diabetic patients in Ahmadu Bello University Teaching Hospital Zaria, Nigeria. Diabetes Metab Syndr. 2019;13(5):2967-292. http://dx.doi.org/10.1016/j.dsx.2019.07.057. PMid:31437811.

57. Huebschmann AG, Regensteiner JG, Vlassara H, Reusch JE. Diabetes and glicoxidation end products. Diabetes Care. 2006;29(6):1420-32. http://dx.doi.org/10.2337/dc05-2096. PMid:16732039.

58. Jakus V, Rietbrock N. Advanced glycation end-products and the progress of diabetic vascular complications. Physiol Res. 2004;53(2):131-42. PMid:15046548.

59. Goldin A, Beckman JA, Schmidt A, Creager MA. Review. Advanced glycation end products: sparking the development of diabetic vascular injury. Circulation. 2006;114(6):597-605. http://dx.doi.org/10.1161/CIRCULATIONAHA.106.621854. PMid:16894049.

60. Ahmed N. Advanced glycaton endproducts-role in pathology of diabetic complications. Diabetes Res Clin Pract. 2005;67(1):3-21. http://dx.doi.org/10.1016/j.diabres.2004.09.004. PMid:15620429.

61. Jay D, Hitomi H, Griendling KK. Oxidative stress and diabetic cardiovascular complications. Free Radic Biol Med. 2006;40(2):183-92. http://dx.doi.org/10.1016/j.freeradbiomed.2005.06.018. PMid:16413400.

62. Lapolla A, Fedele D, Traldi P. Glyco-oxidation in diabetes and related diseases. Clin Chim Acta. 2005;357(2):236-50. http://dx.doi.org/10.1016/j.cccn.2005.03.032. PMid:15939413.

63. Babu PV, Sabitha KE, Shyamaladevi CS. Green tea impedes dyslipidemia, lipid peroxidation, protein glycation and ameliorates $\mathrm{Ca}^{2+}$-ATPase activity in the heart of streptozotocin-diabetic rats. Chem Biol Interact. 2006;162(2):157-64. http://dx.doi.org/10.1016/j.cbi.2006.05.020. PMid:16846594.

64. Joglekar MM, Bavkar LN, Sistla S, Arvindekar AU. Effective inhibition of protein glycation by combinatorial usage of limonene and aminoguanidine through differential and synergistic mechanisms. Int J Biol Macromol. 2017;99:563-8. http://dx.doi.org/10.1016/j.ijbiomac.2017.02.104. PMid:28274869.

65. Bierhaus A, Hofmann MA, Ziegler R, Nawroth PP. AGEs and their interaction with AGE-receptors in vascular disease and diabetes mellitus I. The AGE concept Nawroth. Cardiovasc Res. 1998;37(3):586600. http://dx.doi.org/10.1016/S0008-6363(97)00233-2. PMid:9659442. 
66. Ollas B, Wachowiez B, Stochhmal A, Olessezk W. Inhibition of blood platelet adhesion and aecretion by different phenolics from Yucca achidigera Roezl Bark. Nutr. 2005;21(2):199-206. http://dx.doi.org/10.1016/j.nut.2004.03.024.

67. Keating FK, Sobel BE, Schneider DJ. Effects of increased concentrations of glucose on platelet reactivity in healthy subjects and in patients with and without diabetes mellitus. Am J Cardiol. 2003;92(11):1326-1325. http://dx.doi.org/10.1016/j.amjcard.2003.08.033. PMid:14636925.

68. El Haouari M, Rosado JA. Platelet signaling abnormalities in patients with type 2 diabetes mellitus: A review. Blood Cells Mol Dis. 2008;41(1):119-23. http://dx.doi.org/10.1016/j.bcmd.2008.02.010. PMid:18387322.

69. Grant PJ. Diabetes melito as prothrombotic condition. J Intern Med. 2007;262(2):157-72. http://dx.doi.org/10.1111/j.1365-2796.2007.01824.x. PMid:17645584.

70. Kuhne T, Hornstein A, Semple J, Chang W, Blanchette V, Freedman J. Flow cytometric evaluation of platelet activation in blood collected into EDTA vs. Diatube-H a sodium citate solution supplemented with theophylline, adenosine, and dipyridamole. Am J Hematol. 1995;50(1):40-5. http://dx.doi.org/10.1002/ajh.2830500108. PMid:7668222.

71. Winocour PD. Platelets, vascular disease, and diabetes mellitus [Review]. Can J Physiol Pharmacol. 1994;72(3):295-303. http://dx.doi.org/10.1139/y94-045. PMid:8069776.

72. Freedman JE. Oxidative stress and Platelets. Arterioscler Thromb Vasc Biol. 2008;28(3):11-6. http://dx.doi.org/10.1161/ATVBAHA.107.159178. PMid:18174453.

73. Coughlan MT, Mibus AL, Forbes JM. Oxidative stress and advanced glycation in diabetic nephropathy. Ann N Y Acad Sci. 2008;1126(1):190-3. http://dx.doi.org/10.1196/annals.1433.018. PMid:18448815.

74. Noordzij MJ, Lefrandt JD, Smit AJ. Advanced glycation end products in renal failure: an overview. J Ren Care. 2008;34(4):207-12. http://dx.doi.org/10.1111/j.1755-6686.2008.00038.x. PMid:19090900.

75. Miyata T, Ueda Y, Horie K, Nangaku M, Tanaka S, Van Ypersele de Strihou C, Kurokawa K. Renal catabolism of advanced glycation end products: the fate of pentosidine. Kidney Int. 1998;53(2):41622. http://dx.doi.org/10.1046/j.1523-1755.1998.00756.x. PMid:9461101.

76. Nosadini R. Hypertension and renal complications in type diabetes. Semin Vasc Med. 2002;2(1):10919. http://dx.doi.org/10.1055/s-2002-23101. PMid:16222601.

77. Yadav A, Singh A, Phogat J, Dahuja A, Dabur R. Magnoflorine prevent the skeletal muscle atrophy via Akt/mTOR/FoxO signal pathway and increase slow-MyHC production in streptozotocin-induced diabetic rats. J Ethnopharmacol. 2020;267:113510. http://dx.doi.org/10.1016/j.jep.2020.113510. PMid:33141056.

78. Kordi M, Khoramshahi S, Eshghi S, Gaeeni A, Moosakhani A. The effect of high intensity interval training on some atrophic and anti-atrophic gene expression in rat skeletal muscle with diabetes. Sci Sports. 2020;35(3):e75-81. http://dx.doi.org/10.1016/j.scispo.2019.04.003.

79. Gómez-Marcos MA, Martínez-Salgado C, Grandes G, Recio-Rodríguez Jl, Castaño Sánchez Y, Rodríguez SE, García-Ortiz L. Subclinical and established kidney disease in recently diagnosed hypertensive patients. Med Clin (Barc). 2010;134(6):246-53. PMid:20045531.

80. Lima TFO, Costa MC, Figueiredo ID, Inácio MD, Rodrigues MR, Assis RP, Baviera AM, Brunetti IL. Curcumin, alone or in combination with aminoguanidine, increases antioxidant defenses and glycation product detoxification in streptozotocin-diabetic rats: a therapeutic strategy to mitigate glycoxidative stress. Oxid Med Cell Longev. 2020;2020:1036360.

http://dx.doi.org/10.1155/2020/1036360. PMid:32566072.

\section{Authors' contributions}

ASDS and CSF performed the experiments, collected and analyzed the data; RGFAP, SMSD and MRR designed the study and performed the data evaluation; BCCS and ALMV performed the experiments; FBAP and THA performed the data evaluation; EBF statistical analysis; ASDS and MRR wrote the paper; SAF analysis and evaluation of data and update of article writing. 